
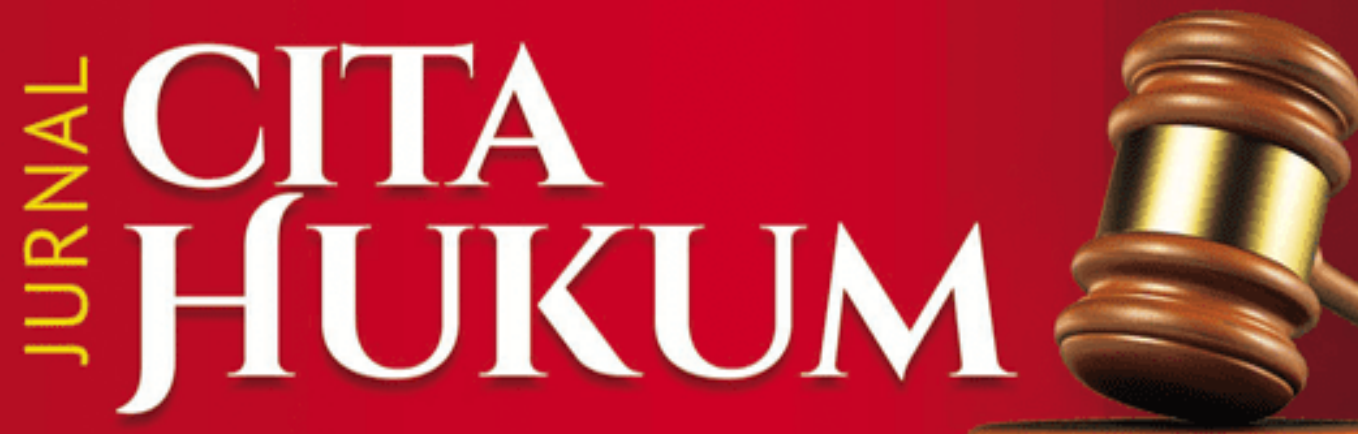

- Penerapan Hukum Jaminan Fidusia Dalam Kontrak Pembiayaan Syariah Muhammad Maksum

- Perlindungan Hukum Terhadap Tenaga Kerja Indonesia (Tinjauan Terhadap UU Nomor 39 Tahun 2004 Tentang Penempatan dan Perlindungan Tenaga Kerja Indonesia) Fatkhul Muin

- Kewenangan Legislasi Dewan Perwakilan Daerah Dalam Reformasi Kelembagaan Perwakilan Pasca Putusan Mahkamah Konstitusi Khamami Zada

- Konsep Pengakuan Bersalah Terdakwa Pada "Jalur Khusus" Menurut RUU KUHAP dan Perbandingannya Dengan Praktek Plea Bargaining Di Beberapa Negara Aby Maulana

- Scope of State Responsibility Against Terrorism in International Law Perspective; Indonesian Cases

Dian Purwaningrum Soemitro \& Indra Wahyu

- Pengendalian Sosial Kejahatan; Suatu Tinjauan Terhadap Masalah Penghukuman Dalam Perspektif Sosiologi Mas Ahmad Yani

- Perubahan Konstitusi dan Reformasi Ketatanegaraan Indonesia Abu Tamrin

- Konsep Perlindungan Hak Cipta Karya Musik Dalam Ranah Hukum Hak Kekayaan Intelektual Dari Tindak Pidana Pembajakan Oksidelfa Yanto 


\section{Jurnal}

\section{CITA HUKUM}

\section{VOL. 3 NO. 1 JUNI 2015}

Diterbitkan oleh Fakultas Syariah dan Hukum Universitas Islam Negeri (UIN) Syarif Hidayatullah Jakarta bekerjasama dengan Pusat Studi Konstitusi dan Legislasi Nasional (POSKO-LEGNAS) UIN

Jakarta. Jurnal Cita Hukum mengkhususkan diri dalam pengkajian Hukum Indonesia dan terbit dua kali dalam satu tahun di setiap bulan Juni dan Desember.

\section{Redaktur Ahli}

Muhammad Atho Mudzhar (UIN Syarif Hidayatullah Jakarta)

Muhammad Amin Suma (UIN Syarif Hidayatullah Jakarta)

Salman Maggalatung (UIN Syarif Hidayatullah Jakarta)

Ahmad Hidayat Buang (University Malaya Malaysia)

Nadirsyah Hosen (Wollongong University Australia)

JM Muslimin (UIN Syarif Hidayatullah Jakarta)

Stephen Koos (Munchen University Germany)

Abdullah Sulaiman (Universitas Trisakti)

Jimly Asshiddiqie (Universitas Indonesia)

Muhammad Munir (IIU Islamabad Pakisatan)

Tim Lindsey (Melbourne University Australia)

Raihanah Azahari (University Malaya Malaysia)

Jaih Mubarok (UIN Sunan Gunung Djati Bandung)

Djawahir Hejazziey (UIN Syarif Hidayatullah Jakarta)

\section{Editor in Chief}

Nur Rohim Yunus

Managing Editor

Muhammad Ishar Helmi

\section{Editors}

Fitria

Indra Rahmatullah

Mara Sutan Rambe

\section{Asisten to The Editors}

Erwin Hikmatiar

\section{Alamat Redaksi}

Fakultas Syariah dan Hukum UIN Syarif Hidayatullah Jakarta

Jl. Ir. H. Juanda 95 Ciputat Jakarta 15412

Telp. (62-21) 74711537, Faks. (62-21) 7491821

Website: www.fsh-uinjkt.net, E-mail: jurnal.citahukum@uinjkt.ac.id

Permalink: http://journal.uinjkt.ac.id/index.php/citahukum 


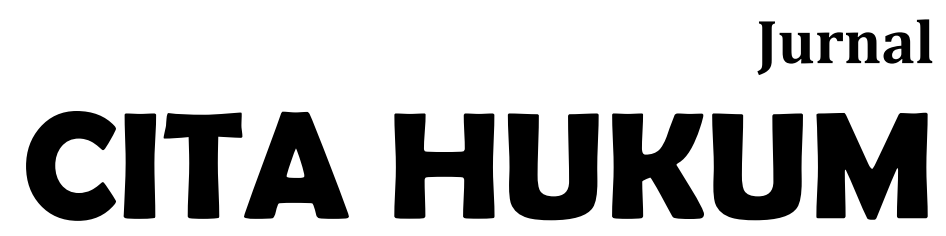

Menyambut baik kontribusi dari para ilmuwan, sarjana, profesional, dan peneliti dalam disiplin ilmu hukum untuk dipublikasi dan disebarluaskan setelah melalui mekanisme seleksi naskah, telaah mitra bebestari, dan proses penyuntingan yang ketat. 


\section{DAFTAR ISI}

1 Penerapan Hukum Jaminan Fidusia Dalam Kontrak Pembiayaan Syariah; Muhammad Maksum

11 Perlindungan Hukum Terhadap Tenaga Kerja Indonesia (Tinjauan Terhadap UU Nomor 39 Tahun 2004 Tentang Penempatan dan Perlindungan Tenaga Kerja Indonesia)

\section{Fathul Muin}

25 Kewenangan Legislasi Dewan Perwakilan Daerah dalam Reformasi Kelembagaan Perwakilan Pasca Putusan Mahkamah Konstitusi Khamami Zada

39 Konsep Pengakuan Bersalah Terdakwa Pada “Jalur Khusus” Menurut RUU KUHAP dan Perbandingannya Dengan Praktek Plea Bargaining di Beberapa Negara

Aby Maulana

67 Scope of State Responsibility Against Terrorism In International Law Perspective; Indonesian Cases

Dian Purwaningrum Soemitro \& Indra Wahyu Pratama

77 Pengendalian Sosial Kejahatan (Suatu Tinjauan Terhadap Masalah Penghukuman Dalam Perspektif Sosiologi)

Mas Ahmad Yani

91 Perubahan Konstitusi dan Reformasi Ketatanegaraan Indonesia Abu Tamrin

99 Konsep Perlindungan Hak Cipta Karya Musik Dalam Ranah Hukum Hak Kekayaan Intelektual Dari Tindak Pidana Pembajakan Oksidelfa Yanto 
115 Tindak Pidana Korupsi (Dugaan Penyalahgunaan Wewenang) Pejabat Publik (Perspektif Undang-Undang Nomor 30 Tahun 2014 Tentang Administrasi Pemerintahan)

Fathudin

133 Perlindungan Hukum Bagi Investor Terhadap Praktik Kejahatan Insider Trading Pada Pasar Modal Di Indonesia

Fadilah Haidar

153 Penyalahgunaan Perjanjian Lisensi Merek Dalam Praktek Bisnis Hak Atas Kekayaan Intelektual Ida Rofida

169 Persamaan Unsur Pokok Pada Suatu Merek Terkenal (Analisis Putusan MA Nomor 162 k/pdt.sus-hki/2014)

Muhammad Dandi Pahusa 


\title{
Konsep Perlindungan Hak Cipta Karya Musik Dalam Ranah Hukum Hak Kekayaan Intelektual Dari Tindak Pidana Pembajakan*
}

\author{
Oksidelfa Yanto \\ Fakultas Hukum dan Magister Ilmu Hukum Universitas Pamulang \\ Jl. Surya Kencana No.1, Tangerang Selatan \\ E-mail: oksidelfayanto@yahoo.co.id
}

\begin{abstract}
Conception of Copy Rights Protection in Musical Creation againts Piracy. Intellectual Property Rights is a rights attributed to a creation as result of a intellectual capacity of human being which give benefits to society, in the science field as well as art, literature and technology. Object of Intellectual Property Rights is human thought. Intellectual Property Rights is a system of recognition, appreciation and legal protection that have the economic values for a wide range of intellectual creation.
\end{abstract}

Key words: protection, Mucical Copy Rights and piracy

\begin{abstract}
Abstrak: Konsep Perlindungan Hak Cipta Karya Musik Dalam Ranah Hukum Hak Kekayaan Intelektual Dari Tindak Pidana Pembajakan. Hak Kekayaan Intelektual atau HKI adalah hak yang timbul dari suatu karya yang dihasilkan dengan menggunakan kemampuan intelektual manusia yang bermanfaat bagi kehidupan masyarakat, di bidang ilmu pengetahuan, seni, sastra dan teknologi. Obyek Kekayaan Intelektual adalah hasil kreasi pikiran manusia. Secara aktual HKI merupakan satu sistem pemberian pengakuan, penghargaan, perlindungan hukum dan mempunyai nilai ekonomis bagi karya-karya intelektual yang mencakup jangkauan yang luas.
\end{abstract}

Kata Kunci:Perlindungan, Hak Cipta Musik, Tindak Pidana Pembajakan

DOI: $\underline{10.15408 / \text { jch.v2i1.2310 }}$

*Naskah diterima: 28 Maret 2015, direvisi: 26 Mei 2015, disetujui untuk terbit: 18 Juni 2015. 


\section{Oksidelfa Yanto}

\section{Pendahuluan}

Penegakan hukum atas hak cipta dilakukan oleh pemegang hak cipta dalam ranah hukum perdata. Meskipun demikian, penegakan hukum atas hak cipta juga bisa melalui pendekatan ranah hukum pidana. Pendekatan dalam ranah hukum pidana dilakukan jika terjadi tindak pidana atau pelanggaran dalam hak cipta tersebut berupa pemalsuan, penggandaan dan pembajakan. Tindakan-tindakan berupa pemalsuan, penggandaan dan pembajakan hak cipta khususnya hak cipta musik selalu menunjukan tingkat yang mengkhawatirkan. Padahal pencipta mempunyai hak eksklusif dan hak-hak lainnya atas karya ciptaannya, dan orang lain diwajibkan untuk menghormatinya.

Berdasarkan uraian diatas, tulisan ini selanjutnya akan membahas tindak pidana hak cipta karya musik sebagai kejahatan khusus ${ }^{1} y a n g$ semakin hari semakin meningkat dalam kehidupan manusia. Dari itulah penulis memberi judul karya tulis ini dengan judul Konsep Perlindungan Hak Cipta Karya Musik dalam Ranah Hukum Hak Kekayaan Intelektual dari Tindak Pidana Pembajakan.

Pada akhirnya, penulis menyadari bahwa tulisan ini tentu tidak akan mampu menjawab semua persoalan pembajakan hak cipta karya musik. Namun setidaknya tulisan ini dapat dijadikan bahan dialog secara tidak langsung dengan banyak pihak mengenai pentingnya hak cipta karya musik dilindungi, baik di masa kini bahkan di masa akan datang.

\section{Pengertian Tindak Pidana}

Berbicara mengenai Tindak Pidana maka sering kita lihat para ahli hukum pidana menggunakan istilah "strafbaar feit" untuk menyebut tindak pidana. Sedangkan di dalam KUHP tidak memberikan penjelasan mengenai perkataan "strafbaar feit" tersebut. Namun demikian perkataan "feit" dalam bahasa Belanda diartikan "sebagian dari kenyataan", sedang "straafbaar" berarti "dapat dihukum", sehingga secara harfiah perkataan "straafbaar feit" berarti "sebagian dari kenyataan yang dapat dihukum" yang sudah barang tentu tidak tepat, oleh karena kelak akan kita ketahui bahwa yang dapat dihukum adalah manusia sebagai pribadi dan bukan kenyataan, perbuatan, atau tindakan².

Kaitannya dengan pengertian "strafbaar feit" Hazewinkel-Suringa, telah membuat suatu rumusan yang bersifat umum dari "strafbaar feit" sebagai suatu perilaku manusia yang pada suatu saat tertentu telah ditolak di dalam sesuatu pergaulan hidup tertentu dan dianggap sebagai perilaku yang harus ditiadakan oleh hukum pidana dengan menggunakan sarana-sarana yang bersifat memaksa yang

${ }^{1}$ Dalam sistem hukum pidana Indonesia timbulnya pengaturan hukum pidana khusus disebabkan karena KUHP sendiri menyatakan tentang kemungkinan adanya Undang-undang pidana diluar KUHP. Dengan kata lain tujuan pengaturan terhadap tindak pidana khusus adalah untuk mengisi kekurangan ataupun kekosongan hukum yang tidak tercakup pengaturannya dalam KUHP, namun pengaturan tersebut tetap masih berada dalam batas-batas yang diperkenankan oleh hukum pidana formil dan materil. Lebih jauh lihatAziz Syamsuddin, Tindak Pidana Khusus, (Jakarta: Sinar Grafika, 2011), h. 8-11.

2P.A.F. Lamintang, Dasar-Dasar Hukum Pidana Indonesia, (Bandung: PT. Cipta Aditya Bakti, 1997),

h. 181

100 - Jurnal Cita Hukum. Vol. 3 No. 1 Juni 2015. ISSN: 2356-1440. 
terdapat didalamnya. ${ }^{3}$ Menurut pompe strafbaarfeit dirumuskan sebagai suatu pelanggaran norma atau gangguan terhadap tata tertib hukum yang dengan sengaja atau tidak sengaja telah dilakukan oleh seorang pelaku dimana penjatuhan hukuman terhadap pelaku adalah penting demi terpeliharanya tertib hukum dan terjaminnya kepentingan hukum. ${ }^{4}$

Pengertian lain dari tindak pidana ialah perbuatan yang melanggar larangan yang diatur oleh aturan hukum yang diancam dengan sanksi pidana. Dalam rumusan tersebut bahwa yang tidak boleh dilakukan adalah perbuatan yang menimbulkan akibat yang dilarang dan diancam sanksi pidana bagi orang yang melakukan perbuatan (pidana) tersebut. ${ }^{5}$ Menurut Moeljatmo, perbuatan pidana adalah perbuatan yang dilarang oleh suatu aturan hukum, larangan yang mana disertai (sanksi) yang berupa pidana tertentu bagi barang siapa yang melanggar aturan tersebut. Dapat juga dikatakan bahwa perbuatan pidana adalah perbuatan yang oleh suatu aturan hukum dilarang dan diancam pidana asal saja dalam pidana itu diingat bahwa larangan ditunjukan pada perbuatan (yaitu suatu keadaan atau kejadian yang ditimbulkan oleh kelakuan orang), sedangkan ancaman pidananya ditujukan kepada orang yang menimbulkan kejadian itu. ${ }^{6}$

Beberapa definisi dari tindak pidana diatas, memberikan gambaran bahwa perbedaan definisi tidak menjadikan masalah tindak pidana yang dilakukan berbeda ancaman hukumannya. Yang terpenting adalah isi dari pengertian tindak pidana. Sebab dalam teori tentang tindak pidana disebutkan bahwa tiada seorang pun dapat dipidana kecuali apabila tindakannya itu bersifat melawan hukum dan telah dilakukan berdasarkan "schuld" atau kesalahan, baik sengaja maupun tidak sengaja. Dengan demikian, apabila ada suatu kejahatan atau tindak pidana yang dilakukan oleh seseorang yang berkaitan dengan pemalsuan dan pembajakan maka seseorang tersebut dapat dikatakan sebagai pelaku tindak pidana yang melakukan kesalahan, dan sesuai UUHC maka pelakunya dihukum menurut ketentuan pasal 72 dan pasal 113 UUHC.

\section{Pelaku Tindak Pidana}

Pertama, Orang Perorangan/Bersama-sama. Dalam kasus pembajakan hak cipta karya musik selalu ditemukan pelaku dari kejahatan tersebut. ${ }^{7}$ Penulis melihat bahwa pelakunya bukan saja para cukong atau pemilik dari penggandaan suatu produk, namun bisa juga pihak-pihak yang lain misalnya, penjual, pengedar dan pemakai dari produk bajakan karya cipta. Dalam hukum pidana hanyalah orangatau

${ }^{3}$ Ibid., h.182

${ }^{4}$ Ibid.,h.182

5Suharto, R.M, Hukum Pidana Materil, (Unsur-unsur Obyektif Sebagai Dasar Dakwaan), (Jakarta: Sinar Grafika, 1996), h.28-29

${ }^{6}$ Moeljatmo, Asas-asas hukum Pidana, (Jakarta: Rineka Cipta, 2000), h . 54

${ }^{7}$ Negara dalam menjatuhkan pidana bagi pelaku haruslah menjamin kemerdekaan individu pelaku dan menjaga supaya pribadi pelaku tetap dihormati. Hal ini dikarenakan bahwa tujuan dari kebijakan pemidanaan yaitu menetapkan suatu pidana namun tidak melupakan perlindungan dalam upaya penegakan Hak Asasi Manusia. 


\section{Oksidelfa Yanto}

orang perorangan atau secara bersama-sama yang dapat dimintakan pertanggungjawaban pidana dari apa yang sudah diperbuatnya dan bersifat melawan hukum. Dengan kata lain, hanya manusia yang dapat melakukan tindak pidana dan hanya manusia yang dapat dituntut serta dibebani pertanggungjawaban pidana baik secara perorangan maupun secara bersama-sama.

Sebagaimana diuraikan terdahulu, bahwa unsur tindak pidana itu adalah perbuatan orang, hal ini dapat disimpulkan berdasarkan :Pertama, rumusan delik dalam Undang-undang lazim dimulai dengan kata-kata:"barang siapa yang..." kata "barang siapa" ini tidak dapat diartikan lain dari pada "orang". Kedua, dalam pasal 10 Kitab Undang-undang Hukum Pidana (KUHP) disebabkan jenis-jenis pidana yang dapat dikenakan kepada tindak pidana yaitu:Pertama, Pidana Pokok yang terdiri dari: 1). Pidana mati. 2). Pidana penjara. 3). Pidana kurungan. 4). Pidana denda yang dapat diganti dengan pidana kurungan. Kedua, Pidana tambahan, yang terdiri dari; 1). Pencabutan hak-hak tertentu. 2). Perampasan barang-barang tertentu. 3). Pengumuman keputusan hakim.

Dalam pemeriksaan perkara dan juga sifat dari hukum pidana yang dilihat ada/tidaknya kesalahan pada terdakwa, memberi petunjuk bahwa yang dapat dipertangguangjawabkan itu adalah manusia. Pengertian kesalahan yang dapat berupa kesengajaan dan kealpaan itu merupakan sikap dalam batin manusia.

Kedua,Korporasi/Badan Usaha, Soetan K. Malikoel Adil secara etimologis, menguraikan pengertian korporasi: "Korporasi, corporatie(Belanda), corporation, (Inggris), korporation (Jerman)berasal dari kata "corporatio" dalam bahasa latin. Seperti halnya dengan kata-kata lain yang berakhir dengan "tio", maka "corporatio" sebagai kata benda (substantivum), berasal dari kata kerja "corporatio", yang banyak dipakai orang pada jaman abad pertengahan atau sesudah itu. Corporare sendiri berasal dari kata "corpus" (Indonesia=badan), yang berarti memberikan badan atau membadankan. Dengan demikian maka akhirnya "corporatio" itu berarti hasil dari pekerjaan membadankan, dengan lain perkataan badan yang dijadikan orang, badan yang diperoleh dengan perbuatan manusia sebagai lawan terhadap badan manusia, yang terjadi menurut alam. ${ }^{8}$

Dalam Kitab Undang-Undang Hukum Pidana Indonesia (KUHP) secara tegas belum menerapkan prinsip-prinsip kejahatan korporasi ${ }^{9}$ (korporasi sebagai pelaku).

8 Mardjono Reksodiputro, Pengabdian Seorang Guru Besar Hukum Pidana, (Depok Bidang Study Hukum Pidana Sentra UI, Sentra HAM FA UI, Badan Penerbit FH UI,2007), h.568.

9Sally. A. Simpson yang mengutip pendapat John Braithwaite menyatakan kejahatan korporasi adalah "conduct of a corporation, or employees acting on behalf of a corporation, which is proscribed and punishable by law". Simpson menyatakan bahwa ada tiga ide pokok dari definisi Braithwaite mengenai kejahatan korporasi. Pertama, tindakan ilegal dari korporasi dan agen-agennya berbeda dengan perilaku kriminal kelas sosio-ekonomi bawah dalam hal prosedur administrasi. Karenanya, yang digolongkan kejahatan korporasi tidak hanya tindakan kejahatan atas hukum pidana, tetapi juga pelanggaran atas hukum perdata dan administrasi. Kedua, baik korporasi (sebagai "subyek hukum perorangan "legal persons") dan perwakilannya termasuk sebagai pelaku kejahatan (as illegal actors), dimana dalam praktek yudisialnya, bergantung pada antara lain kejahatan yang dilakukan, aturan dan kualitas pembuktian dan penuntutan. Ketiga, motivasi kejahatan yang dilakukan korporasi bukan bertujuan untuk keuntungan pribadi, melainkan pada pemenuhan kebutuhan dan pencapaian keuntungan organisasional. Tidak menutup kemungkinan motif tersebut ditopang pula oleh norma operasional (internal) dan sub-kultur 
Meskipun demikian, KUHP telah mengatur mengenai pengurus korporasi yang melakukan "kejahatan korporasi" dengan atas nama korporasi atau perusahaan. ${ }^{10}$

Dalam literatur hukum pidana, penerapan prinsip pertanggungjawaban korporasi ini telah mengalami perkembangan yang demikian pesat sejalan dengan meningkatnya kejahatan korporasi itu sendiri. Pada awalnya, korporasi belum diakui sebagai pelaku dari suatu tindak pidana, karenanya tanggungjawab atas tindak pidana dibebankan kepada pengurus korporasi.

\section{Teori-Teori Pemidanaan}

Tujuan serta fungsi pemidanaan, tidak terlepas dari teori-teori tentang pemindanaan yang ada. ${ }^{11}$ Salah satu teori tersebut yaitu teori absolute atau pembalasan. Dalam teori tersebut dijelaskan pemidanaan harus dicari pada kejahatan itu sendiri untuk menunjukkan kejahatan itu sebagai dasar hubungan yang dianggap sebagai pembalasan, imbalan terhadap orang yang melakukan kejahatan atau perbuatan jahat. Oleh karena itu kejahatan itu menimbulkan penderitaan bagi si korban. ${ }^{12}$

Pemidanaan bagi pelaku pembajakan hak cipta karya musik ditinjau dari tujuannya adalah untuk memberikan pembalasan atas kejahatan yang sudah dilakukan oleh para pelakunya. Dengan demikian jika kita hubungan dengan teori yang ada dalam hukum pidana, maka teori absolute memandang pemidanaan merupakan pembalasan atas kesalahan yang dilakukan. ${ }^{13}$

Disamping teori absolute ada juga teori teologis. Teori teologis yang memandang bahwa pemidanaan bukan pembalasan akan tetapi bertujuan untuk melindungi kepentingan masyarakat. Dalam hal ini adalah kepentingan pada pencipta karya musik atas hasil karya ciptanya yang memiliki nilai ekonomi. Teori ini juga dikenal dengan teori tujuan. ${ }^{14}$

Gabungan dari kedua teori diatas, maka selanjutnya kita mengenai teori absolute teologis. Satu sisi melihat pemidanaan sebagai tujuan untuk melindungi masyarakat dan pada sisi lain pembalasan atas perbuatan pelaku. Namun sesungguhnya tujuan hakiki dari pemidanaan adalah untuk menimbulkan efek jera dari pelaku ataupun masyarakat. Bagi pelaku dengan dipidana akan berfikir ulang

\footnotetext{
organisasional. Lebih jauh lihatLihat bloq Timur Abimanyu, Kejahatan Korporasi Dalam Penerapan Sanksi Hukum Berdasarkan UU No. 25 Tahun 2003Serta Implementasinya.

${ }^{10}$ Mengenai ini dapat dilihat pada Pasal 398 KUHP yang menjelaskan bahwa jika seorang pengurus atau komisaris perseroan terbatas, maskapai andil Indonesia atau perkumpulan korporasi yang dinyatakan dalam keadaan pailit atau yang diperintahkan penyelesaian oleh pengadilan, diancam dengan pidana penjara paling lama satu tahun empat bulan dan "jika yang bersangkutan turut membantu atau mengizinkan untuk melakukan perbuatan-perbuatan yang bertentangan dengan anggaran dasar, sehingga oleh karena itu seluruh atau sebagian besar dari kerugian diderita oleh perseroan, maskapai, atau perkumpulan.

${ }^{11}$ Muladi dan Barda Nawawi Arief, Teori-Teori dan Kebijakan Pidana (Bandung: Alumni, 1992),

12Satochid Kartanegara, Hukum Pidana Bagian Satu, (Jakarta: Balai Lektor Mahasiswa), h. 56

13Satochid Kartanegara, Hukum Pidana Bagian Satu, h. 56.

14Djoko Prakoso, Hukum Penitensir Di Indonesia, (Bandung: Armico, 1998), h.20
} 


\section{Oksidelfa Yanto}

untuk mengulangi perbuatan, sedangkan bagi masyarakat akan takut untuk berbuat pidana, karena pelaku tindak pidana akan dipernjara. ${ }^{15}$

Dari beberapa penjabaran teori pemidanaan diatas, dalam kaitannya dengan tindak pidana bidang hak cipta khususnya yang berkaitan dengan karya musik, maka orang tidak seenaknya lagi melakukan pembajakan atas karya cipta seseorang. Orang akan berfikir berkali-kali untuk menjiplak atau menciplak karya orang lain. Karena setiap kejahatan dibalas dengan hukuman, hukuman tersebut bertujuan agar orang tidak melakukan kembali kejahatan. Agar kemudian orang takut untuk melakukan kejahatan. Termasuk kejahatan pembajakan hak cipta karya musik. Pembalasan dengan menjatuhi hukuman bagi orang yang melakukan kesalahan merupakan suatu bentuk pertanggungjawaban atas suatu perbuatan yang sudah dilakukannya. Pertanggungjawaban pidana hanya bisa dituntut apabila tindak pidana itu dilakukan dengan kesalahan. Artinya meskipun tindak pidana tersebut dilakukan memenuhi unsur kesalahan namun apabila tidak mampu bertanggungjawab kepadanya tidak dapat dikenakan sanksi pidana apapun. ${ }^{16}$

\section{Faktor Penyebab Terjadinya Tindak Pidana (hak cipta musik)}

Banyaknya faktor-faktor yang menyebabkan terjadinya tindak pidana atau kejahatan. Brantinghan menyebutkan bahwa faktor-faktor yang mempengaruhi kejahatan ${ }^{17}$ yaitu: Pertama, faktor ekonomi. Dinyatakan bahwa orang yang tidak memiliki pekerjaan dan kurangnya pendapatan menyebabkan kesenjangan yang tinggi antara kebutuhan ekonomi yang diharapkan dan kebutuhan ekonomi yang nyata. ${ }^{18} \mathrm{Kedua}$, faktor sosial. Orang melakukan kejahatan karena faktor sosial dapat dikategorikan kepada: (a) belajar kejahatan secara individual, (b) belajar kejahatan dalam institusi yang ada, dan (c) sistem sosial. Faktor sosial ini dapat digambarkan dalam matriks berikut:

\begin{tabular}{|c|c|c|}
\hline Heterogen & Stimulasi & Seleksi \\
\hline Diferensiasi Struktural & Differensiasi Personalitas & Mobilitas antarperan \\
\hline Integrasi Fornial & Impersonalitas & Isolasi \\
\hline Anomie & Alienasi & Deviasi \\
\hline
\end{tabular}

\footnotetext{
${ }^{15}$ Ibid.

${ }_{16}$ Mahmud Mulyadi dan Feri Antoni Surbakti, Politik Hukum Pidana Terhadap Kejahatan Korporasi, (Jakarta: PT. Sofmedia, 2010), h.7.

${ }^{17}$ Erlangga Masdiana, Pola Penanganan Kejahatan di Ibukota, Makalah disampaikan pada Seminar Nasional KriminologiForum Kajian Kriminologi Pasca Sarjana Universitas Indonesia, Jakarta, 19 Oktober 2002, h. 5-6.

${ }^{18}$ Dari kenyataan ini adanya waktu luang yang banyak dan kesempatan yang dimilikinya untuk melakukan kejahatan, maka ia akan melakukan kejahatan. Selain itu tidak adanya pekerjaan dan kurangnya pendapatan juga mempengaruhi pemilikan seseorang, pemilikan yang sangat terbatas tersebut mendapatkan tekanan hidup yang tinggi. Misalnya seorang kepala keluarga yang harus bisa menghidupkan anggota keluarganya, maka ia akan mendapatkan tekanan dari pihak keluarga untuk dapat memenuhi kebutuhan keluarga. Akibat tekanan sosial-ekonomi tersebut menumbuhkan masalah-masalah sosial yang besar dihadapi seseorang. Pada saat inilah orang bisa terjerumus kedalam bentuk kejahatan.
}

104 - Jurnal Cita Hukum. Vol. 3 No. 1 Juni 2015. ISSN: 2356-1440. 
Ketiga, faktor kesempatan. Faktor ini dikaitkan dengan adanya barang yang berlimpah, keamanan barang secara fisik, tingkat pengawasan dan kesempatan untuk melakukan kejahatan. Keempat, faktor Sistem Peradilan Pidana (SPP).Faktor perlakuan pandang bulu terhadap para pelaku kejahatan menimbulkan kejahatan menjadi kebal (immune), kejahatan atau pelakunya bisa membeli hakim, jaksa dan para penegak hukum lainnya secara tertutup atau terbuka.

Teori Sosial menjelaskan bahwa perilaku kejahatan adalah hasil kerusakan sistem dan struktur sosial. Seorang penjahat dari keluarga yang bercerai, mengalami masa kecil yang sulit, hidup di lingkungan sosial yang miskin dan banyak terjadi pelanggaran hukum, tidak memiliki pendidikan yang baik, memiliki gangguan fisik dan mental dan berbagai kesulitan psikososial lainnya. Kejahatan ada dimana-mana, disetiap tempat, kejahatan tampak dengan berbagai bentuknya. Kejahatan di kota akan terjadi lebih banyak di banding di desa. Itu karena konsentrasi penduduk ada di kota. Banyak suku bangsa, budaya, agama dan kepentingan. ${ }^{19}$

Adapun faktor-faktor penyebab terjadinya tindak pidana hak cipta karya musik adalah. Pertama, faktor ekonomi. Dalam hal ini mahalnya harga DVD/VCD original membuat masyarakat Indonesia lebih memilih untuk membeli karya bajakan yang harganya jauh lebih murah. Faktor ekonomi juga dapat dilihat dari tingginya angka pengangguran, sehingga orang kemudian menjual barang-barang bajakan. Faktor ekonomi ini kemudian menjadi alasan orang membeli dan menjual barangbarang bajakan. Kedua, penegakan hukum tidak konsisten. Aparat pengakan Hukum kurang tegas dan kurang serius dalam menindak para pelaku pembajakan terhadap barang bajakan Indonesia.Buktinya para pelaku dan pengguna barang-barang bajakan bertebaran disudat-sudut kota.

Dalam kehidupan sehari-hari tentu tidak sedikit orang yang berkilah untuk menghalalkan kejahatan. Disinilah partisipasi masyarakat harus dikembangkan untuk dapat menangani masalah kejahatan dibeberapa wilayah komunitas. ${ }^{20}$ Beberapa komunitas itu antara lain adalah: (a) komunitas spacial yang berada dilingkungan tempat tinggalnya, (b) komunitas profesional yaitu membuat sistem pencegahan dan penanggulangan kejahatan di wilayah pekerjaannya, dan (c) komunitas primordial yaitu membuat sistem koordinasi antara mereka yang berada diwilayah etnik atau asal daerah tertentu.

\section{Bentuk Tindak Pidana Hak Cipta Musik}

Pada umumnya bentuk tindak pidana hak cipta antara lain berupa pengambilan, pengutipan, perekaman, pertanyaan, dan pengumuman sebagian atau seluruh ciptaan orang lain dengan cara apapun tanpa izin pencipta/pemegang hak cipta, bertentangan dengan undang-undang atau melanggar perjanjian. Dilarang undang-undang artinya undang-undang hak cipta tidak memperkenankan perbuatan itu dilakukan oleh orang yang tidak berhak, karena tiga hal yakni:

\footnotetext{
${ }^{19}$ Erlangga Masdiana,"Kejahatan dan Pembangunan", Majalah Forum Keadilan, Nomor. 6, 15 Juni 2003, h.26.

${ }^{20}$ Masdiana, Op.Cit. h. 9.
}

Fakultas Syariah dan Hukum UIN Syarif Hidayatullah Jakarta - 105 


\section{Oksidelfa Yanto}

1) Merugikan pencipta/pemegang hak cipta, misalnya memfotokopi sebagian atau seluruhnya ciptaan orang lain kemudian dijualbelikan kepada masyarakat luas;

2) Merugikan kepentingan Negara, misalnya mengumumkan ciptaan yang bertentangan dengan kebijakan pemerintah di bidang pertahanan dan keamanan atau;

3) Bertentangan dengan ketertiban umum dan kesusilaan, misalnya memperbanyak dan menjual video compact disc (VCD) porno.

Pembajakan terhadap karya orang lain seperti rekaman adalah salah satu bentuk dari tindak pidana hak cipta musik yang dilarang dalam Undang-Undang Hak Cipta. Pekerjaannya liar, tersembunyi, dan tidak diketahui orang banyak apalagi oleh petugas penegak hukum dan pajak. Pekerjaan tersembunyi ini dilakukan untuk menghindarkan diri dari penangkapan pihak kepolisian. Hal ini dapat lihat dalam bentuk pelanggaran counterfeit dan piracy. Counterfeit merupakan bentuk pembajakan dengan melakukan penggadaan ulang suatu album karya rekaman, dalam bentuk sama sekali mirip dengan aslinya baik dalam kemasan album, ilustrasi cover maupun susunan lagunya. Kualitas dari album bajakan ini tentu saja tidak terjamin. Counterfeit lebih dikenal sebagai album rekaman aspal (asli/palsu). Pembajakan atas karya rekaman yang dilakukan dengan menggandakan langsung sebuah album yang sedang laris, kemasannya direproduksi sebagaimana aslinya. ${ }^{21}$

Bentuk pelanggaran yang lain adalahpiracy. Piracy merupakan bentuk pembajakan karya rekaman yang dilakukan dengan memasukan berbagai lagu yang sedang populer kedalam suatu album, dikenal dengan istilah "kompilasi". Bentuk pembajakan ini paling ditakuti dalam industri musik karena dapat mematikan kesempatan penjualan dari beberapa album rekaman secara bersamaan.Piracy atau pembajakan merupakan kegiatan produksi karya-karya yang sudah diterbitkan oleh otoritasi tertentu untuk di distribusi kepada publik dengan tujuan memperoleh keuntungan tanpa diberikan ijin dari otorisasi tersebut.Banyak sekali pembajakan bentuk ini di pusat-pusat perbelanjaan.Bahkan mall dimana banyak pedagang yang dengan bebas dan leluasa menjual dan mengedarkan album hasil pembajakan karya seni tersebut. ${ }^{22}$

Dari ulah pembajak tersebut telah merugikan negara triliunan rupiah. Para pembajak hak cipta karya musik tidak akan mungkin menunaikan kewajiban hukum untuk membayar pajak kepada negara sebagaimana layaknya warga negara yang baik. Pembajakan merupakan salah satu dampak negatif dari kemajuan iptek di bidang grafika dan elektronika yang dimanfaatkan secara melawan hukum (ilegal) oleh mereka yang ingin mencari keuntungan dengan jalan cepat dan mudah.

\section{Sanksi Pidana Pelaku Kejahatan Hak Cipta Karya Musik}

Undang-Undang memberikan sanksi bagi siapa saja yang tidak melindungi karya cipta seseorang dengan melakukan penciplakan atau pembajakan tanpa izin

\footnotetext{
${ }^{21}$ Ahmad Kemal Firdaus, Pelanggaran Hak Cipta Dalam Industri Musik dan Penegakan Hukumnya, Lembaga Bantuan Hukum, Jawa Tengah, 13 November 2014.

${ }^{22}$ Ibid.
}

106 - Jurnal Cita Hukum. Vol. 3 No. 1 Juni 2015. ISSN: 2356-1440. 
dari pemilik hak cipta. Lebih jauh dalam Pasal 72 UU No. 19 Tahun 2002 sudah ditentukan bentuk perbuatan pelanggaran hak cipta karya musik sebagai delik undang-undang (wet delict) yang dibagi tiga kelompok, yakni:

1) Dengan sengaja dan tanpa hak mengumumkan, memperbanyak suatu ciptaan atau memberi izin untuk itu. Termasuk perbuatan pelanggaran ini antara lain melanggar larangan untuk mengumumkan, memperbanyak atau memberi izin untuk itu setiap ciptaan yang bertentangan dengan kebijaksanaan pemerintah di bidang pertahanan dan keamanan negara, kesusilaan, dan ketertiban umum;

2) Dengan sengaja memamerkan, mengedarkan atau menjual kepada umum suatu ciptaan atau barang-barang hasil pelanggaran hak cipta. Termasuk perbuatan pelanggaran ini antara lain penjualan buku dan VCD bajakan;

3) Dengan sengaja dan tanpa hak memperbanyak penggunaan untuk kepentingan komersial suatu program komputer.

Dari ketentuan pasal 72 tersebut, ada dua golongan pelaku pelanggaran hak cipta karya musik yang dapat diancam dengan sanksi pidana. Pertama, pelaku utama adalah perseorangan maupun badan hukum yang dengan sengaja melanggar hak cipta atau melanggar larangan undang-undang. Termasuk pelaku utama ini adalah penerbit, pembajak, penjiplak, dan pencetak.

Kedua, pelaku pembantu adalah pihak-pihak yang menyiarkan, memamerkan atau menjual kepada umum setiap ciptaan yang diketahuinya melanggar hak cipta atau melanggar larangan Undang-Undang Hak Cipta. Termasuk pelaku pembantu ini adalah penyiar, penyelenggara pameran, penjual, dan pengedar yang menyewakan setiap ciptaan hasil kejahatan/pelanggaran hak cipta atau larangan yang diatur oleh undang-undang. Kedua golongan pelaku pelanggaran hak cipta diatas dapat diancam dengan sanksi pidana oleh ketentuan UU No. 19 Tahun 2002. Pelanggaran dilakukan dengan sengaja untuk niat meraih keuntungan sebesar-besarnya, baik secara pribadi, kelompok maupun badan usaha yang sangat merugikan bagi kepentingan para pencipta. ${ }^{23}$

Jika kita lihat pengaturan tentang ketentuan pidana atau hukuman dalam Undang-Undang Hak Cipta, maka kejahatan pembajakan hak cipta karya musik dikategorikan sebagai tindak yang diatur dalam Pasal 72 ayat (2) yang berbunyi: Barang siapa dengan sengaja menyiarkan, memamerkan, mengedarkan atau menjual kepada umum suatu ciptaan atau barang hasil pelanggaran hak cipta atau hak terkait sebagaimana dimaksud pada ayat (1) dipidana dengan pidana penjara paling lama 5 (lima) tahun dan/atau denda paling banyak Rp. 500.000.000 (lima ratus juta rupiah).

Sementara itu akibat adanya perubahan atas UUHC Nomor 19 tahun 2002, maka ketentuan pidana bagi pelaku kejahatan hak cipta sekarang diatur dalam Pasal 112 hingga Pasal 120 UU Nomor 28 tahun 2014 tentang Hak Cipta. Ketentuan mengenai pembajakan karya cipta secara lebih spesifik ditegaskan dalam Pasal 113 ayat 4 yang berbunyi; "Setiap orang yang memenuhi unsur sebagaimana dimaksud pada ayat (3) yang dilakukan dalam bentuk pembajakan, dipidana dengan pidana

\footnotetext{
${ }^{23}$ Andi Hamzah, Asas-Asas Hukum Pidana,(Jakarta: Rineka Cipta, 1994), h. 92.
} 


\section{Oksidelfa Yanto}

penjara paling lama 10 (sepuluh) tahun dan/atau pidana denda paling banyak Rp. 4.000.000,000,00 (empat miliar rupiah).

Dalam Kitab Undang-undang Hukum Pidana (KUHP) juga mengatur mengenai tindak pidana hak cipta. Dalam pasal 480 KUHP disebutkan: "Di pidana dengan pidana penjara selama-lamanya empat tahun atau denda sebanyakbanyaknya sembilan ratus rupiah: 1) Karena bersalah menadah, barangsiapa membeli, menyewa, menukari, menerima gadai, menerima sebagai hadiah atau karena mau mendapat untung, menjual, menyewakan, menukarkan, menggadaikan, membawa, menyimpan atau menyembunyikan sesuatu barang yang diketahuinya atau patut dapat disangkanya, bahwa barang itu diperoleh karena kejahatan; 2) Barangsiapa mengambil untung dari hasil sesuatu barang, yang diketahuinya atau patut dapat disangkanya bahwa barang-barang itu diperoleh karena kejahatan.

Dari ketentuan Undang-Undang diatas, terlihat bahwa ancaman pidana bagi pelaku pelanggaran hak cipta karya musik sangat tegas sekali. Untuk itu, persoalan yang mendasar yang paling penting sekarang adalah bagaimana law enforcementdalam pelanggaran HKI ini dapat dioptimalkan dan diterapkan dilapangan. Pelaku pelanggaran tersebut harus di kenai sanksi pidana sesuai dengan hukum yang berlaku. Hanya dengan cara seperti itulah perlindungan atas karya cipta terutama karya cipta musik dapat dilindungi.

\section{Perlindungan Hak Cipta}

Perlindungan hak cipta tidak diberikan kepada ide atau gagasan karena karya cipta harus memiliki bentuk yang khas, bersifat pribadi dan menunjukkan keaslian sebagai ciptaan yang lahir berdasarkan kemampuan, kreatifitas atau keahlian, sehingga ciptaan itu dapat dilihat, dibaca atau didengar. ${ }^{24}$

Dalam UU Hak Cipta telah diatur mengenai; Pertama, perlindungan hak cipta dilakukan dengan waktu lebih panjang; Kedua, perlindungan yang lebih baik terhadap hak ekonomi para pencipta dan/atau pemilik hak terkait, termasuk membatasi pengalihan hak ekonomi dalam bentuk jual putus (sold flat); Ketiga, penyelesaian sengketa secara efektif melalui proses mediasi, arbitrase, atau pengadilan, serta penerapan delik aduan untuk tuntutan pidana.

Keempat, pengelola tempat perdagangan bertanggung jawab atas tempat penjualan dan/atau pelanggaran hak cipta dan/atau hak terkait di pusat tempat perbelanjaan yang dikelolanya; Kelima, hak cipta sebagai benda bergerak tidak berwujud dapat dijadikan objek jaminan fidusia;Keenam, Menteri diberi kewenangan

${ }^{24}$ Dalam Undang-Undang, ciptaan yang dilindungi adalah ciptaan dalam bidang ilmu pengetahuan, seni dan sastra yang mencakup: Buku, program komputer, pamflet, perwajahan (lay out) karya tulis yang diterbitkan dan semua hasil karya tulis lain. Ceramah, kuliah, pidato, dan ciptaan lain yang sejenis dengan itu. Alat peraga yang dibuat untuk kepentingan pendidikan dan ilmu pengetahuan. Lagu atau musik dengan atau tanpa teks. Drama atau drama musikal, tari, koreografi, pewayangan dan pantomime. Seni rupa dalam segala bentuk seperti seni lukis, gambar, seni ukir, seni kaligrafi, seni pahat, seni patung, kolase dan seni terapan. Arsitektur. Peta. Seni batik. Fotografi. Sinematografi. Terjemahan, tafsir, saduran, bunga rampai, database, dan karya lain dari hasil pengalih wujudan. 
untuk menghapus ciptaan yang sudah dicatatkan, apabila ciptaan tersebut melanggar norma agama, norma susila, ketertiban umum, pertahanan dan keamanan negara, serta ketentuan peraturan perundang-undangan.

Ketujuh, pencipta, pemegang hak cipta, pemilik hak terkait menjadi anggota LembagaManajemen Kolektif agar dapat menarik imbalan atau royalti; Kedelapan, pencipta dan/atau pemilik hak terkait mendapat imbalan royalti untuk ciptaan atau produk hak terkait yang dibuat dalam hubungan dinas dan digunakan secara komersial; Kesembilan, Lembaga Manajemen Kolektif yang berfungsi menghimpun dan mengelola hak ekonomi pencipta dan pemilik hak terkait wajib mengajukan permohonan izin operasional kepada Menteri; Kesepuluh, penggunaan hak cipta dan hak terkait dalam sarana multimedia untuk merespon perkembangan teknologi informasi dan komunikasi.

Sebagai benda bergerak, baik dalam UU 19/2002 dan UU Hak Cipta baru diatur mengenai cara mengalihkan hak cipta. Akan tetapi dalam Pasal 16 ayat (1) UU Hak Cipta Baru ditambahkan bahwa hak cipta dapat dialihkan dengan wakaf. Masih terkait dengan hak cipta sebagai benda bergerak, dalam UU 19/2002 tidak diatur mengenai hak cipta sebagai jaminan. Akan tetapi, dalam Pasal 16 ayat (3) UU Hak Cipta Baru dikatakan bahwa hak cipta adalah benda bergerak tidak berwujud yang dapat dijaminkan dengan jaminan fidusia.

Mengenai jangka waktu perlindungan hak cipta yang lebih panjang, dalam Pasal 29 ayat (1) UU 19/2002 disebutkan bahwa jangka waktu perlindungan hak cipta adalah selama hidup pencipta dan berlangsung hingga 50 tahun setelah pencipta meninggal dunia, sedangkan dalam UU Hak Cipta Baru, masa berlaku hak cipta dibagi menjadi 2 (dua) yaitu masa berlaku hak moral dan hak ekonomi. Hak moral pencipta untuk (i) tetap mencantumkan atau tidak mencatumkan namanya pada salinan sehubungan dengan pemakaian ciptaannya untuk umum; (ii) menggunakan nama aliasnya atau samarannya; (iii) mempertahankan haknya dalam hal terjadi distorsi ciptaan, mutilasi ciptaan, modifikasi ciptaan, atau hal yang bersifat merugikan kehormatan diri atau reputasinya, berlaku tanpa batas waktu (Pasal 57 ayat (1) UU Hak Cipta Baru). Sedangkan hak moral untuk (i) mengubah ciptaannya sesuai dengan kepatutan dalam masyarakat; dan (ii) mengubah judul dan anak judul ciptaan, berlaku selama berlangsungnya jangka waktu hak cipta atas ciptaan yang bersangkutan (Pasal 57 ayat (2) UU Hak Cipta Baru).

Kemudian untuk hak ekonomi atas ciptaan, perlindungan hak cipta berlaku selama hidup pencipta dan terus berlangsung selama 70 tahun setelah pencipta meninggal dunia, terhitung mulai tanggal 1 Januari tahun berikutnya (Pasal 58 ayat (1) UU Hak Cipta Baru). Sedangkan jika hak cipta tersebut dimiliki oleh badan hukum, maka berlaku selama 50 tahun sejak pertama kali dilakukan pengumuman.

Perlindungan sebagaimana diatur dalam Pasal 58 tersebut hanya berlaku bagi ciptaan berupa: a. Buku, pamflet, dan semua hasil karya tulis lainnya; b. Ceramah, kuliah, pidato dan Ciptaan sejenis lain; c. Alat peraga yang dibuat untuk kepentingan pendidikan dan ilmu pengetahuan; d. Lagu atau musik dengan atau tanpa teks; e. Drama, drama musikal, tari, koreografi, pewayangan, dan pantomim; f. Karya seni rupa dalam segala bentuk seperti lukisan, gambar, ukiran, kaligrafi, seni pahat, 


\section{Oksidelfa Yanto}

patung, atau kolase; g. Karya arsitektur; h. Peta; dan i. Karya seni batik atau seni motif lain. Akan tetapi, bagi ciptaan berupa: a. Karya fotografi; b. Potret; c. Karya sinematografi; d. Permainan video;e. Program komputer; f. Perwajahan karya tulis; g. Terjemahan,tafsiran, saduran, bunga rampai, basis data, adaptasi, aransemen, modifikasi, dan karya lain dari hasil transformasi; h. Terjemahan, adaptasi, aransemen, transformasi atau modifikasi ekspresi budaya tradisional; i. Kompilasi ciptaan atau data, baik dalam format yang dapat dibaca dengan program komputer atau media lainnya; j. Kompilasi ekspresi budaya tradisional selama kompilasi tersebut merupakan karya yang asli; berlaku selama 50 tahun sejak pertama kali dilakukan pengumuman. (Pasal 59 ayat (1) UU Hak Cipta Baru). Kemudian untuk ciptaan berupa karya seni terapan, perlindungan hak cipta berlaku selama 25 tahun sejak pertama kali dilakukan pengumuman (Pasal 59 ayat (2) UU Hak Cipta Baru).

UU Hak Cipta Baru ini juga melindungi pencipta dalam hal terjadi jual putus (sold flat). Ciptaan buku, dan/atau semua hasil karya tulis lainnya, lagu dan/atau musik dengan atau tanpa teks yang dialihkan dalam perjanjian jual putus dan/atau pengalihan tanpa batas waktu, hak ciptanya beralih kembali kepada pencipta pada saat perjanjian tersebut mencapai jangka waktu 25 tahun (Pasal 18 UU Hak Cipta Baru). Hal tersebut juga berlaku bagi karya pelaku pertunjukan berupa lagu dan/atau musik yang dialihkan dan/atau dijual hak ekonominya, hak ekonomi tersebut beralih kembali kepada pelaku pertunjukan setelah jangka waktu 25 tahun (Pasal 30 UU Hak Cipta Baru).

\section{Tinjauan Umum Tentang Musik}

Musik merupakan salah satu bagian terpenting dalam kehidupan manusia. Selain menghibur, musik dapat pula mencerdaskan manusia dan terapi kesehatan untuk mengobati stress pada manusia. Bahkan musik dapat meredakan rasa sakit kepala sekitar 20\% (dua puluh persen). ${ }^{25}$

Menurut Aristoteles, musik mampu mendamaikan hati yang gundah, mempunyai terapi rekreatif dan menumbuhkan jiwa patriotisme. ${ }^{26}$ Lantunan Musik biasanya diciptakan untuk menggambarkan keadaan tertentu, baik itu susah, senang, tentang alam atau kehidupan. Dengan menikmati musik sesuai yang disenangi dapat memberikan suatu inspirasi, ketenangan, bahkan musik dapat mencerdaskan. ${ }^{27}$

Otak manusia terdiri dari dua bagian, otak kiri dan otak kanan. Otak kiri bekerja untuk fungsi logika, analisa. Sedangkan otak kanan bekerja untuk tugas visual, ruang (geometric), creativity, mood, emotion, dan sebagainya. ${ }^{28}$ Secara teknis,

${ }^{25}$ Kathleen, Lives of The Musicians: Good Times, Bad Times, (London: HMH Book for Young Readers, 2011), h. 23.

26Sarah Sefira, Kisah 1001 Musik Asyik Paling Berpangaruh di Dunia, (Jakarta: PT. Grasindo, 2014), h.

13.

${ }^{27}$ lbid

${ }^{28}$ Fajar Tama, Musik Adalah Inspirasi, www/ / blogspot.com

110 - Jurnal Cita Hukum. Vol. 3 No. 1 Juni 2015. ISSN: 2356-1440. 
musik dibangun oleh beberapa unsur. Diantaranya adalah bunyi, yaitu getaran yang dapat ditangkap oleh organ telinga manusia, yang selanjutnya disebut "nada" ${ }^{29}$

Berdasarkan kamus besar Bahasa Indonesia, musik merupakan ilmu atau menyusun nada atau suara dalam urutan, kombinasi, dan hubungan temporal untuk menghasilkan komposisi (suara) yang mempunyai kesatuan dan kesinambungan, selain itu musik juga dapat diartikan sebagai nada atau suara yang disusun yang menggunakan alat-alat yang dapat menghasilkan bunyi-bunyi tersebut). ${ }^{30}$

Pengertian musik sering kali dibedakan dengan pengertian lagu. Menurut kamus Besar Indonesia lagu merupakan ragam suara yang berirama (dalam bercakapcakap, bernyanyi, membaca, dan lain-lain), atau nyanyian. Dari pengertian tersebut dapat disimpulkan bahwa musik dan lagu merupakan dua hal yang berkaitan erat satu sama lain. Pengertian musik lebih luas dari pada pengertian lagu. Ada yang berpendapat bahwa lagu merupakan bagian dari suatu karya musik, yaitu karya musik sendiri meliputi karya musik yang menggunakan lirik maupun karya musik tanpa lirik (instrumentalia). ${ }^{31}$

Dave Benson kemudian menyebutkan, musik itu adalah getaran udara, dan udara adalah gas yang terdiri dari atom dan molekul, penambahan dan pengurangan tekanan terhadap molekul inilah yang menyebabkan adanya perbedaan getaran (dan di interpretasikan sebagai bunyi) dalam kondisi temperatur normal, molekul udara bergerak atau bergetar dengan kecepatan 450 sampai dengan 500 meter per detik. ${ }^{32}$

Don Campbell, seorang ahli musik terkemuka dunia dalam bidang hubungan antara musik dan penyembuhan, menyatakan bahwa musik bukan hanya sebagai sarana hiburan, melainkan obat bagi tubuh dan jiwa. Menurutnya, musik juga irama yang memberikan makna untuk membangkitkan gairah dan semangat hidup untuk memaknai hidup. Mendengarkan, menghayati, dan menikmati alunan musik adalah kegiatan yang menyenangkan dan bisa membuat kita nyaman. ${ }^{33}$

\section{Konsep Ideal Penanggulangan Kejahatan Hak Cipta Dikaitkan Dengan Banyaknya Pembajakan VCD dan DVD Karya Musik}

Kebijakan perlindungan hak cipta karya musik setidaknya perlu mencakup dua aspek utama yakni kebijakan anti pembajakan yakni segenap kebijakan yang dimaksud untuk mencegah dan menghilangkan peluang bagi tumbuhnya aksi pembajakan hak cipta karya musik dan kebijakan kontra pembajakan yakni merupakan segenap instrumen yang menitikberatkan pada aspek penindakan

\footnotetext{
${ }^{29}$ Christine Ammer, The Facts on File Dictionary of Music, London:2004, h. 262. British menyebut "nada" dengan "note", sedangkan Amerika adalah "tone" untuk menyebutkan nada sebagai bunyi (audio), dan "note" sebagai lambang nada (tekstual).

${ }^{30}$ Departemen Pendidikan Dan Kebudayaan, Kamus Besar Bahasa Indonesia, (Jakarta: Balai Pustaka, 1995), h. 602.

${ }^{31}$ Ibid, h. 486.

${ }^{32}$ Dave Benson, Mathematic and Music, Departement of Mathematics (USA: University of Georgia, Athens, 2004), h. 1.

${ }^{33}$ Bebbi Okatara, Enam Jam Jago Teknik Olah Vokal Menuju Penyanyi Profesional, (Jakarta: Gudang Ilmu, 2011), h.1.
} 


\section{Oksidelfa Yanto}

terhadap pelaku pembajakan hak cipta karya musik. Inilah yang kemudian penulis artikan sebagai suatu konsep ${ }^{34}$ baru dalam mengatasi persoalan pembajakan hak cipta.

Konsep tersebut berupa pembentukan badan baru dalam mengatasi persoalan pembajakan hak cipta. Ini merupakan upaya-upaya yang sudah seharusnya dipikirkan. Selama ini, upaya penanggulangan aksi pembajakan hak cipta karya musik berupa VCD dan DVD yang dilakukan oleh masing-masing institusi yang ada sesuai dengan kompetensi dari masing-masing belum memberikan hasil yang maksimal. Kita punya Direktorak Jenderal Hak Kekayaan Intelektual sekarang diubah menjadi Direktorat Jenderal Kekayaan Intelektual. Selain itu, kita punya Yayasan Karya Cipta Indonesia dan ada Asosiasi Industri Remakan Indonesia. Namun semua itu tidak memiliki kekuatan untuk melakukan penindakan langsung, termasuk juga dalam proses pelaksanaan hukumannya.

Untuk membentuk badan baru dalam menanggulangi aksi pembajakan hak cipta karya musik tentunya harus dapat dijelaskan kepada publik tentang alasan dan kebutuhan pembentukan badan baru tersebut sehingga ada alasan yang rasional yang dapat diterima oleh publik.

Artinya, badan baru yang akan dibentuk untuk penanggulangan pembajakan hak cipta karya musik jangan kemudian menimbulkan pro dan kontra pada masyarakat. Misalnya, nanti badannya bernama Badan Nasional Penanggulangan Pembajakan Hak Cipta (BNPPHC) karya musik. Badan tersebut harus dapat berfungsi untuk melakukan penangkapan, penindakan bahkan penahanan kepada pelaku pembajakan, baik produser, termasuk penjual dan pembeli. Disamping itu badan tersebut juga harus dibentuk melalui Undang-Undang. Sehingga nanti kekuatan tugasnya bisa maksimal. Artinya, dengan Undang-Undang tersebut, maka badan yang dibentuk bisa memainkan perannya dan tidak sekedar formalitas belaka. Jadi cakupan kewenangan badan penanggulangan pembajakan harus sangat luas, yakni mulai dari penangkapan dan penindakan, bahkan penahanan. Selanjutnya proses hukum untuk dapat dihukumnya pelaku diserahkan ke Pengadilan Khusus yang disediakan untuk menjatuhkan hukuman sebagaimana dimaksud dalam Undangundang Hak Cipta yang ada. Saat ini kita memiliki pengadilan niaga dalam perkara gugatan hak cipta.

\section{Penutup}

Pertama, bentuk tindak pidana hak cipta antara lain berupa pengambilan, pengutipan, perekaman, pertanyaan, dan pengumuman sebagian atau seluruh ciptaan orang lain dengan cara apapun tanpa izin pencipta/pemegang hak cipta, bertentangan dengan undang-undang atau melanggar perjanjian.

\footnotetext{
${ }^{34}$ Dalam Kamus Besar Bahasa Indonesia (1995:456) konsep diartikan sebagai rancangan ide atau pengertian yang diabstrakkan dari pengertian kongkret, gambaran mental dari objek atau apapun yang ada di luar bahasa yang digunakan oleh akal budi untuk memahami hal-hal lain.
} 
Kedua, faktor-faktor penyebab terjadinya tindak pidana hak cipta karya musik adalah. Pertama, faktor ekonomi. Faktor ekonomi kemudian menjadi alasan orang membeli dan menjual barang-barang bajakan. Kedua, faktor penegakan hukum yang tidak konsisten. Aparat penegakan hukum kurang tegas dan kurang serius dalam menindak para pelaku pembajakan terhadap barang bajakan Indonesia.

Ketiga,Bentuk perlindungan hak cipta karya musik adalah dengan membentuk badan baru berdasarkan Undang-undang. Pembentukan badan ini dimaksud bertujuan untuk melindungi karya cipta seseorang dari tindakan pemalsuan, penggandaan dan pembajakan.

\section{Pustaka Acuan}

\section{$\underline{\text { Buku }}$}

Andi Hamzah, Asas-Asas Hukum Pidana, Rineka Cipta, Jakarta, 1994.

Ahmad Kemal Firdaus, Pelanggaran Hak Cipta Dalam Industri Musik Dan Penegakan Hukumnya, Lembaga Bantuan Hukum, Jawa Tengah, 13 November 2014

Abi Bakar Jabir al-Jazairi, Haramkah Musik Dan Lagu? (Al-I'lam bi Anna al-'Azif wa alGhina Haram).

Abdurrahman al-Baghdadi, Seni Dalam Pandangan Islam, (Bogor: Islamic, 2010). Islam Memandang Seni, (Jakarta: Gema Insani, 2004),

Aziz Syamsuddin, Tindak Pidana Khusus, (Jakarta: Sinar Grafika, 2011).

Bebbi Okatara, Enam Jam Jago Teknik Olah Vokal Menuju Penyanyi Profesional, (Jakarta: Gudang Ilmu, 2011).

Bruce B. Lawrence, Guru Besar Studi Islam di Duke University, Amerika Serikat, dalam bukunya; Islam Tidak Tunggal, yang diterbitkan PT. Serambi Ilmu Semesta, tahun 2014.

Burhan Ashofa, Metode Penelitian Hukum, (Jakarta: Rineka Cipta, 1998).

Christine Ammer, The Facts on File Dictionary of Music, (London: 2004).

Dave Benson, Mathematic and Music, Departement of Mathematics (USA: University of Georgia, Athens, 2004).

Djoko Prakoso, Hukum Penitensir Di Indonesia, (Bandung: Armico, 1998).

Erlangga Masdiana, Pola Penanganan Kejahatan Di Ibukota. Makalah disampaikan pada Seminar Nasional Kriminologi.Forum Kajian Kriminologi Pasca Sarjana Universitas Indonesia. Jakarta. 19 Oktober 2002.

Fajar Tama, Musik Adalah Inspirasi, www//blogspot.com

John Handol M, Nyanyian Lucifer, (Yogyakarta: Yayasan ANDI, 2002),

Kathleen,Lives of The Musicians: Good Times, Bad Times, (London: HMH Book for Young Readers, 2011).

Muladi dan Barda Nawawi Arief, Teori-Teori dan Kebijakan Pidana (Bandung: Alumni, 1992). 


\section{Oksidelfa Yanto}

Mardjono Reksodiputro, Pengabdian Seorang Guru Besar hukum Pidana, Depok Bidang Study Hukum Pidana Sentra UI, Sentra HAM FA UI, Badan Penerbit FH UI,2007.

Moeljatmo, Asas-asas hukum Pidana, Jakarta, Rineka Cipta, 2000.

Mahmud Mulyadi dan Feri Antoni Surbakti, Politik Hukum Pidana Terhadap Kejahatan Korporasi, (Jakarta: PT. Sofmedia, 2010).

P.A.F. Lamintang, Dasar-Dasar Hukum Pidana Indonesia. Bandung, PT. Cipta Aditya Bakti, 1997.

,Hukum Pidana Indonesia. Bandung, Sinar Baru, 1984.

Satochid Kartanegara, Hukum Pidana Bagian Satu, (Jakarta: Balai Lektor Mahasiswa).

Suharto, R.M, Hukum Pidana Materil (Unsur-unsur Obyektif sebagai dasar Dakwaan), Jakarta, sinar Grafika, 1996.

Sarah Sefira, Kisah 1001 Musik Asyik Paling Berpangaruh di Dunia, (Jakarta: PT. Grasindo, 2014).

TM. Natsir Fathuddin, Kuliah Akhlak, Kajian Sistematis Mengenai Akhlak Terhadap Allah dan Rasulullah SAW, (Bogor: Pesantren Baitussalam, 2008).

Widodo, Sistem Pemidanaan dalam Cyber Crime, (Yogyakarta: Laksbang Mediatama,2009).

\section{Undang-Undang}

Undang-Undang Hak Cipta Nomor 19 Tahun 2002 Tentang hak Cipta

\section{$\underline{\text { Majalah }}$}

Erlangga Masdiana, Kejahatan dan Pembangunan", (Majalah Forum Keadilan, Nomor. 6, 15 Juni 2003).

Nuim Hidayat, Musik dalam Islam: Bolehkah?, (Majalah Hidayatullah, 12 September 2012).

\section{Kamus}

Departemen Pendidikan Dan Kebudayaan, Kamus Besar Bahasa Indonesia, (Jakarta, Balai Pustaka, 1995) 
